\title{
Shifting and Incidence of Indirect Taxes on Tobacco and Petroleum Products in Pakistan
}

\author{
by \\ MoHammad Irfan*
}

\section{INTRODUCTION}

Indirect taxes have always occupied a dominant position in the tax structure of Pakistan. This has worried economists of various inclinations because of the widespread belief that indirect taxes tend to be regressive and interfere with efficient resource allocations. The resource allocations effects of such taxes is not considered in this paper which restricts itself to an analysis of the incidence of excise duties on tobacco products and petroleum products. Prior to the levy of export duties in 1972, two of the most important sources of indirect taxes were excise and import duties on petroleum and tobacco products. Together these groups accounted for roughly 60 per cent of excise duty collections and one third of indirect taxes in 1969-70. Moreover, additional taxes levied year after year seldom by-pass these two groups. A detailed analysis of the incidence of these two taxes will, therefore, constitute a necessary and important feature of the incidence of taxes in Pakistan.

Indirect taxes are considered to be regressive on the assumptions that they are shifted forward to consumers and that consumption expenditures are more equitably distributed than income. Both propositions need to be checked especially where the structure of indirect taxes is very selective as in Pakistan.

Studies on tax incidence and tax shifting are scarce in Pakistan. Some attempts have been made to study the incidence of the entire tax structure but in these cases a number of general and arbitrary assumptions were resorted to. There has been one direct study on the shifting of taxes and another set of studies that shed some evidence on this aspect.

*The author is a Staff Economist at the PIDE. He is grateful to Dr. Javed Azfar and Dr. S.E. Guisinger for guidance and helpful comments for improving the study. Thanks are also due to Dr. G.M. Radhu, Mr. M.G. Chouldry and Mr. A.R. Kemal for helpful comments on an earlier draft of this paper. The author alone is responsible for any error. 
In each study it has been found that contrary to general impressions indirect taxes are not shifted forward to the consumer. The study by Radhu [10] tackled this problem directly. A number of observations on changes in prices following upon changes in excise.and sates tax rates were collected and price changes were regressed upon tax rate changes for these observations. The regression coefficient was not significantly different from zero and Radhu concluded that the evidence did not support the hypothesis that indirect taxes are shifted forward to the consumer. Most of the observations pertained to small changes in sales tax and no attempt was made to weight commodities by their contribution to excise and sales tax collections. Thus, while his conclusion may have held for most commodities it was not necessarily true for most tax collections. In particular, his exercise included only one observation from the petroleum and tobacco groups and for that observation there was a very close correspondence between the tax rate and increase in price.

The studies by M.L. Pal [4] and M. Alamgir [1] did not concentrate directly upon the shifting of indirect taxes but they did conclude that owing to scarcity profit margins resulting from the licencing system, the import duty did not play a role in determining the price of imported commodities. While it is possible to quarrel with the generalisation of this conclusion to all commodities even for the period to which Pal and Alamgir's studies apply, this behaviour will not hold true after the recent devaluation.

The implications of the studies by Radhu, Pal, and Alamgir concerning shifting conflict radically with the general view that indirect taxes are regressive. If indirect taxes are not shifted forward, then they must be borne by producers and traders, who are in the higher income brackets. It appears, then, that indirect taxes are progressive, since they are paid by upper income groups. However, an understanding, of the total impact of government policies on individual income including the protective effects of tariff and licences, can lead one to the conclusion that the combined impact of commercial and fiscal system is regressive. This would be true if the increases in income created by protection exceed the value of taxes paid out of this protection generated income.

The incidence of the tax structure has been studied by Azfar [2] on separate sets of assumptions which assume in one case that all indirect taxes are shifted forward and in the other that most import duties are borne by the traders. In both cases the taxation system turns out to be progressive although the degree of progressivity is extremely high in the latter case. The important finding of the study is that within the income groups that do not pay income tax (i.e., the bottom 95 per cent of the households) indirect taxes played a progressive role while direct taxes had hardly any incidence. These estimates were based upon fairly arbitrary assumptions on the distribution of taxes on cigarettes and petroleum products, among other items, over income groups.

An attempt has been made in this study to assess the shifting and incidence of taxes on cigarettes and petroleum products on the basis of consumption distribution obtained from producers. The shifting of taxes is discussed in Section-II and tax incidence in Section-III. 


\section{SHIFTING OF TAXES}

Coverage of all types of petroleum products and blends of cigarettes was precluded by lack of data. It was only possible to examine tax price relationship for four items each from the two commodities groups. The period covered is 1953-72 except where mentioned otherwise.

In measuring the magnitude of shifting, price changes are measured by the difference between or the percentage change between the price holding in the month before the tax change and the month after the tax change. Thus if tax rate changes are announced in June, the price change is between May-July of that calender year. This procedure could not be followed for Capstan cigarettes where average wholesale price for the fiscal year had to be used. The price data are taken from the CSO Monthly Statistical Bulletin and pertains to average monthy wholesale prices with the exception of Capstan cigarettes where data is taken from 25 Years of Pakistan in Statistics and pertains to annual average wholesale prices.

Data on tax rates for petroleum products are taken from the Excise Manual, while for cigarettes the source is Central Board of Revenue. The additional duties and cesses, like the refugee tax and defence surcharge, have been taken into account. However, the development surcharge on petroleum products has not been included because it is not explicitly mentioned in budget documents and tends to fluctuate widely. The surcharge represents the difference between the prices fixed by the government and the cost to the seller including his commission. Also excluded from the study are the duties on crude oil, tobacco and other taxes on packing materials of cigarettes. To study the impact of these duties it would have been necessary to allocate their use to specific products or brands which in the absence of information would have involved a high degree of arbitrariness.

To determine the degree of tax shifting regressions have been estimated for both the absolute and percentage difference in prices and taxes, with the tax changes serving as the independent variable. To the extent that the slope coefficient is significant and close to unity, it may be inferred that the tax is passed on fully to the consumer.

It can be seen from the Appendix Table II and III that the movements of taxes and prices are closely related. The exact relationship has been estimated using a simple regression model with two types of data. For each product, regressions were run using absolute changes and percentage changes. The results of the regression are shown in Table 1.

Regression coefficients are significant in all the cases at 5 per cent level of significance, and in most of the cases coefficients are significant even at 1 per cent level. The regressions employing percentage changes of the variables yield lower regression coefficients as compared to the regressions using the absolute changes. The values of the slope coefficients in the case of absolute changes indicate that a very high portion of excise duties is shifted to consumers.

For three products in the petroleum group i.e., Diesel Oil (N.O.S.), Kerosine Oil, and Furnace Oil it was not possible to estimate regressions because 
TABLE I

\begin{tabular}{|c|c|c|c|c|c|c|}
\hline $\begin{array}{l}\text { Name of the } \\
\text { Product }\end{array}$ & $\begin{array}{l}\text { No. of } \\
\text { obser- } \\
\text { vation }\end{array}$ & $\begin{array}{l}\text { Kind of th } \\
\text { changes }\end{array}$ & Equation & $\mathbf{R}^{\mathbf{2}}$ & $T$ & D \\
\hline \multirow[t]{2}{*}{$\begin{array}{l}\text { Motor } \\
\text { Spirit }\end{array}$} & 9 & Percentage & $Y=1.93+56(x)$ & .86 & 7.27 & 2.45 \\
\hline & ”, & Absolute & $Y=4.94+.99(x)$ & .94 & 9.81 & 2.70 \\
\hline \multirow[t]{2}{*}{ Scissors } & 10 & Percentage & $Y=.13+.92(x)$ & .92 & 3.17 & 2.09 \\
\hline & ", & Absolute & $Y=14+.98(x)$ & .88 & 7.82 & 1.42 \\
\hline \multirow[t]{2}{*}{$\begin{array}{l}\text { Passing Show* } \\
\text { Red Lamp }\end{array}$} & 10 & Percentage & $Y=3.38+.13(x)$ & .47 & 2.79 & 1.63 \\
\hline & $"$ & Absolute & $Y=62.39+.81(x)$ & .59 & 3.58 & 1.34 \\
\hline \multirow[t]{2}{*}{ Capstan** } & 9 & Percentage & $Y=1.94+.38(x)$ & .65 & 3.56 & 1.37 \\
\hline & , & Absolute & $Y=.48+.92(x)$ & .62 & 3.38 & 2.68 \\
\hline
\end{tabular}

*Period covered is 1953-66.

***Period covered is 1953-70.

TABLE II

Name of Product

Furnace Oil

Kerosine

Diesel Oil

(N.O.S.)

(1) $+733.33+44+20.65+13+27$
$(2)+26.00+13+10.15+2.20+3$
(1) $+87.50+14$
(2) +
(3) +
23.33
14
$+\quad 7$
$+\quad 25.5$
$\overline{3} .85+\overline{4}$
$+48.31+52$

Changes in tax rate

Change in price

(1) $+233.33+30$
$(3)+130.77+17$

$+15.68$

+
$+\quad 4.95$

$+\quad 7 *$

$+25.36+13 *$

The prices are converted in terms of gallon from the price of ton given in
monthly statistical bulletins. 
of the small number of the changes. For each product there were only three changes in the tax rate, the response of their prices to tax changes is given in table II. This also bears out the direct and close relationship of variations in the tax rate and variations in the prices of the taxed products.

The comparison of price of a brand of cigarettes with its regression coefficients displays an interesting tendency. The lowest priced brands in our analysis, passing show and red lamp, have the least price variations explained by tax rate changes. It seems worth mentioning that major share of passing show and red lamp are consumed by lower income groups.

However, it should be noted that many factors influence the price levels of the products in this study. Ideally, a multi-variate regression model could be fitted that could isolate the independent effect of indirect taxes on the price level. However, owing to the paucity of data, the estimation of a multi-variate regression model was not possible. To determine the importance of the variables not included in the regressions reported in Table I, we have examined the DurbinWatson statistics, No evidence of omitted variables emerged from these tests, though in five cases the results are inconclusive. These tests, alongwith the significance levels of the estimated regressions tend to suggest that tax changes are a major determinant of the price variations included in our regression analysis.

\section{INCIDENCE OF TAXES}

Attempts at estimating or analysing incidence of taxes in Pakistan have been rare. It is, therefore, difficult to adopt a methodology of allocating taxes based upon previous analysis or to compare the results of this exercise with earlier efforts. The method of allocating indirect taxes varies with the nature of the tax and use pattern of the taxed product.

Tax revenues collected from products of widespread use, where the impact of taxes is diffused throughout the economy, can be allocated on the basis of the total consumption expenditure of different income groups. For selective taxes, the allocation of tax revenue in proportion to expenditures on the taxed product is necessary. This, however, requires information regarding consumption patterns in addition to the expenditure data if the rate of tax is not uniform for a qualitatively differentiated product.

In order to obtain a better estimation of the incidence of taxes on cigarettes and petroleum products, information was obtained from a major producer on (i) the preference of consumers in different income group for various brands of cigarettes and (ii) the types of vehicles in operation alongwith their average rate of motor spirit consumption. Application of this data to the income and expenditure distribution provided in the Household Income and Expenditure Survey revealed certain incompatibilities in case of cigarettes. Consequently, some adjustments had to be made in order to arrive at realistic estimates. The detailed assumptions and the results of the exercise are described below. 


\section{Cigarettes}

The groupwise percentage share of income and expenditure on cigarettes is estimated from C.S.O., Household Income and Expenditure Surveys for the years 1968-69 and 1969-70. The information regarding the consumers of different brands of cigarettes obtained through discussions with officials of Pakistan Tobacco Company, which is enumerated below:

(i) The cigarettes of price ${ }^{1}$ upto 30 paisa per ten cigarettes are consumed by the income group of upto Rs. $250 /$ per month.

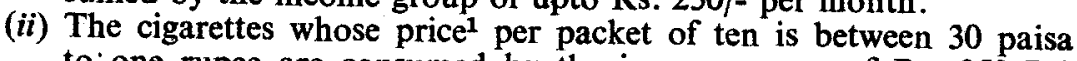
to one rupee are consumed by the income group of Rs. $250-750$ per month.

(iii) The cigarettes having price ${ }^{1}$ above Re. 1/- per packet of ten are smoked by the income group of Rs. 750/- and above per month.

(iv) Ten to fifteen per cent of the lower brands are consumed by the higher income groups and five to ten per cent of the higher brands by lower income groups. (The average figures of 13 per cent and 7 per cent are used respectively).

The results presented in table III immediately point out the inconsistency of the distribution given by the Pakistan Tobacco Company and of the information provided in the Household Income and Expenditure Surveys. It will be seen from the table that:

TABLE III

Progressivity Scale of Excise on Cigarettes**

\begin{tabular}{lcccccc}
\hline $\begin{array}{l}\text { Income } \\
\text { group } \\
\text { Monthly } \\
\text { Income }\end{array}$ & \multicolumn{5}{c}{ Scale of progressivity to Excise } & \multicolumn{2}{l}{ Revenue } \\
\cline { 2 - 8 } & \multicolumn{3}{c}{ Income as base } & \multicolumn{4}{c}{ Expenditure on Cigarette as a base } \\
\cline { 2 - 8 } & $1970-71$ & $1971-72$ & $1971-72 *$ & $1970-71$ & $1971-72$ & $1971-72 *$ \\
\hline $0-250$ & 1 & 1 & 1 & 1 & 1 & 1 \\
$250-750$ & 0.84 & 0.74 & 0.73 & 0.56 & 0.50 & 0.48 \\
750 and above & 1.35 & 1.28 & 1.16 & 0.88 & 0.84 & 0.76 \\
\hline
\end{tabular}

* Including surcharge.

* These progressivity scales were derived by equating the index of tax incidence for the lowest income group to unity. The construction of the indexes of tax incidence is explained in the
Appendix Tables.

(i) the excise duty on cigarettes is regressive with expenditure on cigarettes as a base.

(ii) the tax is more regressive with the expenditure on cigarettes as a base than income as a base; and

(iii) the middle income group (Rs. $250-750$ p.m.) pays a considerably lower proportion of the tax than the income group below it.

${ }^{1}$ Retail price exclusive of surcharge. 
The result that the tax is regressive with expenditure on cigarettes as a base is inconsistent with the assumption that higher taxed (higher quality) cigarettes are consumed by the upper income groups. The result that the tax is more regressive with expenditure on cigarettes rather income as base implies that their physical consumption is considerably more skewed than the income distribution which is improbable for such a common consumer item as cigarettes. Both these results indicate that there is a major conflict between the distribution of cigarettes provided by the Pakistan Tobacco Company and the distribution reported in the Household Income and Expenditure Survey.

In order to correct these deficiencies, two separate calculations have been carried out. In the first, the data regarding the expenditure on cigarettes provided in the Households Income and expenditure Survey have been rejected and replaced by multiplying the amount of cigarettes of different categories allocated to each income group by the average price of the cigarettes. The results of this exercise are presented in table No. TV. It will be seen from the table that the tax becomes progressive with the newly constructed series of expenditure on cigarettes as the base.

TABLE IV

Progressivity Scale of Excise on Cigarettes

\begin{tabular}{|c|c|c|c|c|c|c|}
\hline \multirow{2}{*}{$\begin{array}{l}\text { Income } \\
\text { Group } \\
\text { Monthly } \\
\text { Income }\end{array}$} & \multicolumn{3}{|c|}{ C.S.O. Expenditure as a base } & \multicolumn{3}{|c|}{$\begin{array}{l}\text { Alternative Estimate of } \\
\text { Expenditure as a base }\end{array}$} \\
\hline & $1970-71$ & $1971-72$ & $1971-72 *$ & $1970-71$ & $1971-72$ & $1971-72 *$ \\
\hline $\begin{array}{c}0-250 \\
250-750 \\
750 \& \text { above }\end{array}$ & $\begin{array}{l}1 \\
0.56 \\
0.88\end{array}$ & $\begin{array}{l}1 \\
0.50 \\
0.84\end{array}$ & $\begin{array}{l}1 \\
0.48 \\
0.76\end{array}$ & $\begin{array}{l}1 \\
1.32 \\
1.75\end{array}$ & $\begin{array}{l}1 \\
1.52 \\
1.82\end{array}$ & $\begin{array}{l}1 \\
1.43 \\
1.62\end{array}$ \\
\hline
\end{tabular}

Inclusive of surcharge.

The lower contribution of middle income group which has distorted the scale on the basis of income finds its explanation in the disproportionate quantitative allocation of cigarettes consequent upon the application of consumption pattern provided by Pakistan Tobacco Company. The middle income group is 32 per per of the population but the cigarettes allocated are 21 per cent for 1970-71 and 16 per cent for 1971-72. Bearing in mind that cigarettes consumption expenditure is roughly three times in urban households as compared to rural, the urban population distribution appears to be more relevant where the middle group claims around 46 per cent.

In the second, the quantitative allocation of cigarettes is made congruent with population distribution. This, however, introduced slight changes in the consumption pattern. The lowest and the middle income group still get 7 per cent of the next higher brand, but the higher income groups fail to maintain the old shares. Now, the middle group is allocated 27 per cent of the lower brands instead of 13 per cent, while the top group is allocated 10 per cent of the next lower brands, which is three percentage points less than the previous position. 

table below.

The results based on the proportionate distribution are presented in

\author{
TABLE V
}

Progressivity Scale of Excise on Cigarettes

\begin{tabular}{|c|c|c|c|c|c|c|}
\hline \multirow{2}{*}{$\begin{array}{l}\text { Income } \\
\text { Group } \\
\text { Monthly } \\
\text { Income } \\
\end{array}$} & \multicolumn{3}{|c|}{ Income as base } & \multicolumn{3}{|c|}{$\begin{array}{c}\text { Expenditure on cigarettes as } \\
\text { a base }\end{array}$} \\
\hline & $1970-71 \mid$ & 1971-72 | & $1971-72 * \mid$ & $1970-71$ & $|1971-72|$ & $1971-72 *$ \\
\hline $\begin{array}{c}0-250 \\
250-750 \\
750 \& \text { above }\end{array}$ & $\begin{array}{c}1 \\
1.24 \\
1.44\end{array}$ & $\begin{array}{l}1 \\
1.30 \\
1.53\end{array}$ & $\begin{array}{c}1 \\
1.25 \\
1.35\end{array}$ & $\begin{array}{l}1 \\
1.27 \\
1.70\end{array}$ & $\begin{array}{l}1 \\
1.37 \\
1.85\end{array}$ & $\begin{array}{l}1 \\
1.28 \\
1.63\end{array}$ \\
\hline
\end{tabular}

* Including surcharge.

The incidence is progressive on either base as is borne out by the table above. The surcharge, however, impairs this progressivity. The negative effect of the surcharge appeared in all three tables. The regressive impact of the surcharge arises from a uniform levy within slabs. ${ }^{2}$

\title{
PETROLEUM PRODUCTS
}

The revised estimate of the excise collection from P.O.L. group is 901.2 million for 1971-72. Out of this Rs. 397.6 million (43 per cent) accrues from motor spirit including jet fuels. Because of this extent of contribution motor spirit can be considered a major item. A separate incidence analysis for this
product is made.

\section{Motor Spirit}

The constraints of data led to the separate estimation for Karachi and Punjab province. The vehicle population of the Punjab is obtained from Excise and Taxation Office Lahore, while for Karachi the source of information is Pakistan Burmah Shell Limited. This company also provided the information regarding daily average consumption by type of vehicles. The idea of ownership pattern and utilization mode is framed on the basis of discussion with the officials of the said concern, which is described below:

1. The ownership of private cars is assumed to be exclusively in the income group of Rs. 1000/- and above per month.

2. The ownership of motor cycles/scooters is heavily concentrated in the income bracket of 400-1000 per month. Eighty five per cent of these vehicles is attributed to this group. Out of the remaining fifteen percent, five per cent is allocated to income groups of $250-400$, and ten per cent to income groups of 1000 and above.

A slab represents a particular range of retail prices for cigarettes per packet of ten. Excise duty and surcharge is imposed on these slabs which are at present four in number i.e. to Rs. 1/- and Rs. 1/- and above. 
3. The petrol consumption by private motor cars is divided into $60: 40$ (for Karachi) between domestic expenditure and business expenditure. The latter accounts for the expenditure by corporate bodies, business men, which is shifted onward. In case of Punjab province the ratio is modified to $70: 30$.

4. The petrol consumption by taxis, rickshaws, minibuses, is allocated 90 per cent to income groups below 1000 per month and 10 per cent to above.

5. Petrol consumption in connection of business [as in (3) and trucks etc.], is distributed among different income groups on the basis of their respective shares in total expenditure.

6. The petrol consumption by Government is ignored. The results in brief are presented below.

TABLE VI

Scale of Progressivity in Excise on Motor Spirit by different Income Group

\begin{tabular}{l|c|c|c|c}
\hline Income Group & \multicolumn{2}{|c|}{ Karachi } & Punjab Province \\
\cline { 2 - 5 } & $\begin{array}{c}\text { Income as } \\
\text { base }\end{array}$ & $\begin{array}{c}\text { Expenditure on } \\
\text { transport as } \\
\text { base }\end{array}$ & Income & $\begin{array}{c}\text { Expenditure on } \\
\text { transport as } \\
\text { base }\end{array}$ \\
\hline $0-250$ & 1 & 1 & 1 & 1 \\
$250-400$ & 1.38 & 0.84 & 1.28 & 0.84 \\
$400-1000$ & 2.11 & 1.10 & 3.37 & 1.73 \\
1000 and above & 3.78 & .96 & 11.80 & 3.09 \\
\hline
\end{tabular}

There is substantial divergence in the relative scales for Karachi and Punjab Province. The former is purely an urban area while the latter has both rural and urban areas. The incidence is progressive on the basis of income and more pronounced in case of Punjab. On the basis of transport expenditure, however, there is no element of progressivity for Karachi. In the case of the Punjab the second income group pays the least. The progressivity scale of Punjab is taken for the country as a whole. The average of the scales on the basis of income and expenditure is used to allocate the excise revenue collected from motor spirit in 1971-72. This is added with the rest of the products of the group. The procedure adopted is discussed below.

1. Half of the diesel is distributed on the basis of expenditure on transport on non-durables.

2. Kerosine is allocated on the basis of expenditure on kerosine.

3. The distribution of the remaining is done on the basis of total expenditure. 
The expenditure distribution is obtained from C.S.O.'s surveys. The results are presented below in table.

\section{TABLE VII}

Progressivity Scale of Excise on P.O.L. Group 1971-72

\begin{tabular}{c|c|c}
\hline Monthly Income & Income as a base & $\begin{array}{c}\text { Expenditure on transport } \\
\text { as base }\end{array}$ \\
\hline $0-250$ & 1.00 & 1.00 \\
$250-400$ & 1.19 & 0.78 \\
$400-1000$ & 1.78 & 0.91 \\
1000 and above & 7.41 & 1.94 \\
\hline
\end{tabular}

The incidence is progressive on the basis of income. The rate of progressivity rises as one goes from lower to higher income groups. On the basis of transport expenditure the same tendency is missing, though the top group still contributes the highest. The middle two groups pay less than the bottom group. The regressivity on the basis of transport expenditure seems to be due to the nature of the distribution of the said expenditure. Transport expenditure, being the rising function of income, bears a more skewed distribution than income, while around 34 per cent of the excise revenue assumed to be diffused in the economy is allocated on the basis of total expenditure which has more equitable distribution.

The incidence of motor spirit alone seems to be more progressive as compared with the P.O.L. group as a whole. This lends some credibility to the general impression that motor spirit is consumed primarily by the higher income brackets. This exercise, however, suggest that the tax on this product is not without some adverse effects for the lower income groups.

\section{CONCLUSIONS}

The major finding of this study is that during the period 1953 to 1972 the excise duty on cigarettes and petroleum products were shifted forward to the consumer. This finding differs with the earlier studies of indirect taxes in Pakistan which implied that the taxes were borne by producers. Because excise duties on petroleum and cigarettes form a significant share of total indirect tax revenues, the degree of shifting in these products has a major bearing on the determination of the overall incidence of indirect taxes.

Our regression analysis has identified a strong positive relation between the absolute changes in tax rates and the absolute changes in prices for the selected tobacco and petroleum products included in the study. Regressions including percentage change in prices and tax rates show a weaker correlation.

Excise duties on cigarettes have a progressive incidence. The top income group pays at a rate 85 per cent higher than that for the bottom income group. This figure drops to 63 per cent if the surcharge is included. The regressive impact of the surcharge arises from a uniform levy within slabs. The regressivity would be removed if the surcharge were made advalorem. 
The duty on petroleum products has a progressive incidence. This is especially true for motor spirit. The incidence of the tax on motor spirit is less progressive in Karachi than in Punjab suggesting an inverse link between degree of urbanization and the progressivity of the duty.

This study depends on a number of assumptions, which were necessary in view of the scarcity of the data, but which need to be checked in future research. In particular our assumption concerning the expenditure pattern of the different income groups needs to be verified by collecting data on the ownership of vehicles, levels of petroleum consumption by different vehicles by type, and preferences of smokers in each income group for different brands of cigarettes. Also further work on shifting using a multi-variate regression model would clearly isolate the independent effect of tax changes on the product prices, which would provide a better indication of tax shifting than we have presented in this study.

\section{REFERENCES}

1. Alamgir, M. "The Domestic Prices of Imported Commodities in Pakistan. A Further Study." The Pakistan Development Review, Vol. VIII, No. 1, Spring 1968.

2. Azfar, Javed, "Distribution of Income in Pakistan before and After Taxes, 1966-67". An Unpublished Ph.D. thesis.

3. Pal, Mati Lal, "The Determinants of Domestic Prices of Imports" The Pakistan Development Review, Vol. IV, No. 4, Winter, 1964.

4. Pal, Mati Lal, "Domestic Prices of Imports in Pakistan: Extension of Empirical Findings" The Pakistan Development Review Vol V, No. 4, Winter, 1965.

5. Pakistan, Central Board of Revenue, Prevailing Rates of Central Excise Duty on Various Commodities During 1948-49 to 1966-67.

6. Pakistan, Central Statistical Office, Monthly Statistical Bulletins 1952-72.

7. Pakistan, Central Statistical Office, 25 Years of Pakistan in Statistics.

8. Pakistan, Ministry of Finance, Planning and Development, Statistical Division, Household Income and Expenditure Surveys 1968-69 and 1969-70.

9. Pakistan, Ministry of Finance, Fiscal Policy in Pakistan: A Historical Perspective", Vol. II.

10. Radhu, Ghulam Mohammad, "The Relation of Indirect Tax Changes to Price Changes in Pakistan. The Pakistan Development Review, Vol. V, No. 1 Spring, 1965.

11. Rahman, M. Akhlaqur, "The Structure of Taxation in Pakistan", U.B.L. Research Monograph No. 4. (Karachi: UBL, Research Department). 


\section{Appendix}

TABLE I

Tax Structure of Pakistan (Revised Estimates)

(Rs. in Millions)

Name of Tax

1. Taxes on Income

2. Customs

3. Sales Tax

4. Central Excise Duty:

(a) P.O.L. Group

(b) Tobacco

(c) Others

5. Surcharge on Petroleum

6. Surcharge on Natural Gas

7. Surcharge on Cement

8. Rehabilitation Tax

9. Price Equalisation surcharge

10. Other Tax Heads

| 1969-70 | 1970-71 | 1971-72 | 1972-73

$\begin{array}{llll}1022.0 & 1010.0 & 1149.3 & 1052.0\end{array}$

$\begin{array}{llll}1650.0 & 1700.0 & 1342.5 & 2635.0\end{array}$

$\begin{array}{llll}686.0 & 700.0 & 558.5 & 430.0\end{array}$

$\begin{array}{llll}2468.0 & 2490.0 & 2270.8 & 2252.8\end{array}$

$\begin{array}{llll}922.0 & 936.2 & 901.3 & 811.5\end{array}$

$\begin{array}{llll}435.0 & 514.7 & 456.0 & 495.0\end{array}$

$\begin{array}{llll}1111.0 & 1039.1 & 913.5 & 946.3\end{array}$

$\begin{array}{llll}92.5 & 80.5 & 220.6 & 119.8\end{array}$

$\begin{array}{llll}18.3 & 18.2 & 18.4 & 18.2\end{array}$

20.8

17.6

18.0

17.1

36.0

45.2

10.6

14.1

20.7

18.8

23.5

\section{$\begin{array}{lll}6057.6 & 6050.4 & 5618.7\end{array}$}

\section{3}

Source: The Explanatory Memorandum on the Budgets of Government of Pakistan-1970-71, 1971-72, 1972-73 and 1973-74.

* Includes also Rs. 19.4 millions of surcharge on fertilisers. 


\section{TABLE II}

Changes in Tax Rate (Excise) and Prices (Monthly Wholesale Average) on Motor Spirit-Per Imperial Gallon for 1953-72

\begin{tabular}{|c|c|c|c|c|}
\hline \multirow{3}{*}{ Month \& Year } & \multicolumn{4}{|c|}{ Motor Spirit } \\
\hline & \multicolumn{2}{|c|}{ Tax rate changes } & \multicolumn{2}{|c|}{ Price changes } \\
\hline & Percentage & $\begin{array}{c}\text { Absolute } \\
\text { (Paisa) }\end{array}$ & Percentage & $\begin{array}{c}\text { Absolute } \\
\text { (Paisa) }\end{array}$ \\
\hline $\begin{array}{r}3 / 1953 \\
3 / 1954 \\
9 / 1955 \\
2 / 1957 \\
6 / 1962 \\
11 / 1965 \\
6 / 1966 \\
4 / 1971 \\
6 / 1972\end{array}$ & $\begin{array}{l}+60 \\
-25 \\
-10.6 \\
+14.2 \\
+1.3 \\
+25.0 \\
+18.6 \\
+40 \\
+33.3\end{array}$ & $\begin{array}{l}+75 \\
-50 \\
-16 \\
+19 \\
+2 \\
+39 \\
+36 * \\
+100 \\
+100\end{array}$ & $\begin{array}{l}+32.8 \\
-20.0 \\
+\quad 5.0 \\
+7.2 \\
+\quad 14.9 \\
+20.25 \\
+25.00 \\
+18.9\end{array}$ & $\begin{array}{l}+75 \\
-62 \\
+12 \\
+19 \\
- \\
+39 \\
+64 \\
+100 \\
+100\end{array}$ \\
\hline
\end{tabular}

Adjusted the defence surcharge.

Sources: 1. Monthly Statistical Bulletins-CSO for prices.

2. Central Board of Revenue for Tax Rates.

TABLE III

Changes in Excise Rate and Prices of Cigarettes-Capstan, Scissors, Passing Show and Red Lamp (per 1000 Cigarettes)

\begin{tabular}{|c|c|c|c|c|}
\hline \multirow{3}{*}{ Year } & \multicolumn{4}{|c|}{ Capstan } \\
\hline & \multicolumn{2}{|c|}{ Tax rate changes } & \multicolumn{2}{|c|}{ Price changes } \\
\hline & Percentage & $\begin{array}{c}\text { Absolute } \\
\text { (Paisa) }\end{array}$ & Percentage & $\begin{array}{c}\text { Absolute } \\
\text { (Paisa) }\end{array}$ \\
\hline $\begin{array}{l}1953-54 \\
1955-56 \\
1958-59 \\
1962-63 \\
1963-64 \\
1964-65 \\
1965-66 \\
1966-67 \\
1970-71\end{array}$ & $\begin{array}{r}+29.20 \\
+33.26 \\
+47.91 \\
+11.11 \\
+51.11 \\
+25.00 \\
+12.00 \\
+0.84 \\
+17.70\end{array}$ & $\begin{array}{l}+219 \\
+312 \\
+575 \\
+225 \\
+1150 \\
+850 \\
+510 \\
+40 \\
+850\end{array}$ & $\begin{array}{r}+2.71 \\
+5.57 \\
+20.22 \\
+23.16 \\
+9.69 \\
+8.71 \\
+3.48 \\
+4.74\end{array}$ & $\begin{array}{l}+137 \\
+281 \\
+1000 \\
+1313 \\
+677 \\
+668 \\
+290 \\
+410\end{array}$ \\
\hline
\end{tabular}


TABLE III-(contd).

\begin{tabular}{|c|c|c|c|c|}
\hline \multirow{3}{*}{ Month \& Year } & \multicolumn{4}{|c|}{ Scissors } \\
\hline & \multicolumn{2}{|c|}{ Tax rate changes } & \multicolumn{2}{|c|}{ Price changes } \\
\hline & Percentage & $\begin{array}{c}\text { Absolute } \\
\text { (Paisa) }\end{array}$ & Percentage & $\begin{array}{c}\text { Absolute } \\
\text { (Paisa) }\end{array}$ \\
\hline $\begin{array}{l}3 / 53 \\
3 / 58 \\
6 / 59 \\
6 / 62 \\
6 / 63 \\
6 / 65 \\
6 / 66 \\
6 / 70 \\
6 / 71 \\
6 / 72\end{array}$ & $\begin{array}{r}+30 \\
-28.80 \\
+35.60 \\
+8.66 \\
+47.23 \\
+20.00 \\
-14.93 \\
+42.85 \\
+28.57 \\
+22.22\end{array}$ & $\begin{array}{r}+150 \\
-187 \\
+187 \\
+65 \\
+385 \\
+240 \\
-215 \\
+525 \\
+500 \\
+500\end{array}$ & $\begin{array}{r}+3.76 \\
+7.60 \\
+\quad 2.72 \\
+20.70 \\
+10.03 \\
-2.84 \\
+14.28 \\
+13.47 \\
+11.86\end{array}$ & $\begin{array}{r}+119 \\
-215 \\
-\quad 71 \\
+555 \\
+295 \\
+95 \\
+500 \\
+500 \\
+500\end{array}$ \\
\hline
\end{tabular}

\begin{tabular}{|c|c|c|c|c|}
\hline \multirow{3}{*}{ Month \& Year } & \multicolumn{4}{|c|}{ Passing Show and Red Lamp } \\
\hline & \multicolumn{2}{|c|}{ Tax rate changes } & \multicolumn{2}{|c|}{ Price changes } \\
\hline & Percentage & $\begin{array}{c}\text { Absolute } \\
\text { (Paisa) }\end{array}$ & Percentage & $\begin{array}{l}\text { Absolute } \\
\text { (Paisa) }\end{array}$ \\
\hline \multirow[t]{2}{*}{$\begin{array}{l}3 / 1953 \\
6 / 1959 \\
6 / 1961 \\
6 / 1962 \\
6 / 1963 \\
6 / 1966\end{array}$} & $\begin{array}{l}+30 \\
-38.4 \\
+3.2 \\
+5.46 \\
+1.23 \\
+62.50\end{array}$ & $\begin{array}{r}+112 \\
+187 \\
+9.5 \\
+21 \\
+\quad 5 \\
+250\end{array}$ & $\begin{array}{r}+15.23 \\
+0.43 \\
+0.82 \\
+0.27 \\
+16.58\end{array}$ & $\begin{array}{l}+281 \\
+\quad 8 \\
+15 \\
+\quad 5 \\
+320\end{array}$ \\
\hline & & Red Lam & & \\
\hline $\begin{array}{l}3 / 1953 \\
6 / 1962 \\
6 / 1963 \\
6 / 1966\end{array}$ & $\begin{array}{r}+30 \\
+11.53 \\
-48.78 \\
+50.00\end{array}$ & $\begin{array}{l}+37 \\
+18 \\
-100 \\
+50\end{array}$ & $\begin{array}{l}+3.80 \\
+\quad 0.89 \\
+9.83\end{array}$ & $\begin{array}{l}-41 \\
+40 \\
+120\end{array}$ \\
\hline
\end{tabular}

Notes: 1. Prices are yearly wholesale average for capstan for the rest the monthly wholesale average are used.

2. Period covered for capstan is 1953-70, for Passing Show and Red Lamp 1953-66 while for Scissors it is 1953-72.

Sources: 1. Monthly Statistical Bulletins C.S.O. for prices.

2. Central Board of Revenue for tax rates. 
TABLE III-(contd).

\begin{tabular}{|c|c|c|c|c|}
\hline \multirow{3}{*}{ Month \& Year } & \multicolumn{4}{|c|}{ Scissors } \\
\hline & \multicolumn{2}{|c|}{ Tax rate changes } & \multicolumn{2}{|c|}{ Price changes } \\
\hline & Percentage & $\begin{array}{c}\text { Absolute } \\
\text { (Paisa) }\end{array}$ & Percentage & $\begin{array}{c}\text { Absolute } \\
\text { (Paisa) }\end{array}$ \\
\hline $\begin{array}{l}3 / 53 \\
3 / 58 \\
6 / 59 \\
6 / 62 \\
6 / 63 \\
6 / 65 \\
6 / 66 \\
6 / 70 \\
6 / 71 \\
6 / 72\end{array}$ & $\begin{array}{l}+30 \\
+28.80 \\
+35.60 \\
+8.66 \\
+47.23 \\
+20.00 \\
-14.93 \\
+42.85 \\
+28.57 \\
+22.22\end{array}$ & $\begin{array}{l}+150 \\
-187 \\
+187 \\
+65 \\
+385 \\
+240 \\
+215 \\
+525 \\
+500 \\
+500\end{array}$ & $\begin{array}{r}+3.76 \\
-7.60 \\
+\quad 2.72 \\
+20.70 \\
+10.03 \\
-2.84 \\
+14.28 \\
+13.47 \\
+11.86\end{array}$ & $\begin{array}{l}+119 \\
-215 \\
-\quad 71 \\
+\quad 755 \\
+295 \\
+95 \\
+500 \\
+500 \\
+500\end{array}$ \\
\hline
\end{tabular}

\begin{tabular}{|c|c|c|c|c|}
\hline \multirow{3}{*}{ Month \& Year } & \multicolumn{4}{|c|}{ Passing Show and Red Lamp } \\
\hline & \multicolumn{2}{|c|}{ Tax rate changes } & \multicolumn{2}{|c|}{ Price changes } \\
\hline & Percentage & $\begin{array}{c}\text { Absolute } \\
\text { (Paisa) }\end{array}$ & Percentage & $\begin{array}{c}\text { Absolute } \\
\text { (Paisa) }\end{array}$ \\
\hline \multirow[t]{2}{*}{$\begin{array}{l}3 / 1953 \\
6 / 1959 \\
6 / 1961 \\
6 / 1962 \\
6 / 1963 \\
6 / 1966\end{array}$} & $\begin{array}{l}+30 \\
+38.4 \\
+3.2 \\
+5.46 \\
+1.23 \\
+62.50\end{array}$ & $\begin{array}{l}+112 \\
-187 \\
+9.5 \\
+21 \\
+\quad 5 \\
+250\end{array}$ & $\begin{array}{r}+15.23 \\
+\quad 0.43 \\
+0.82 \\
-0.27 \\
+16.58\end{array}$ & $\begin{array}{l}+281 \\
+\quad 8 \\
+\quad 15 \\
-\quad 5 \\
+320\end{array}$ \\
\hline & & Red Lamp & & \\
\hline $\begin{array}{l}3 / 1953 \\
6 / 1962 \\
6 / 1963 \\
6 / 1966\end{array}$ & $\begin{array}{r}+30 \\
+11.53 \\
-48.78 \\
+50.00\end{array}$ & $\begin{array}{l}+37 \\
+18 \\
-100 \\
+50\end{array}$ & $\begin{array}{l}+3.80 \\
+0.89 \\
+9.83\end{array}$ & $\begin{array}{l}+41 \\
+\quad 10 \\
+120\end{array}$ \\
\hline
\end{tabular}

Notes: 1. Prices are yearly wholesale average for capstan for the rest the monthly wholesale average are used.

2. Period covered for capstan is 1953-70, for Passing Show and Red Lamp 1953-66 while for Scissors it is 1953-72.

Sources: 1. Monthly Statistical Bulletins C.S.O. for prices.

2. Central Board of Revenue for tax rates. 
TABLE IV

Excise Collection from Cigarettes by Different Slabs (1967-72)

(Rs. \& Cigarettes in Million*)

\begin{tabular}{l|c|c|c|c}
\hline Year & Slab No. 1 & $\begin{array}{l}\text { Price less } \\
\text { than 15 } \\
\text { paisa per } \\
\text { 10 Cig. }\end{array}$ & Slab No. 2 & \multicolumn{1}{c}{$\begin{array}{c}\text { Price } \\
\text { between } \\
\text { 15-30 paisa } \\
\text { per 10 Cig. }\end{array}$} \\
\hline & Rs. & Cig. & Rs. & Cig. \\
\hline $1966-67$ & 11.37 & 7585.56 & 57.18 & 8807.60 \\
$1967-68$ & 5.60 & 7522.76 & 65.16 & 10024.66 \\
$1968-69$ & 8.83 & 5836.19 & 70.14 & 11777.10 \\
$1969-70$ & 10.67 & 7085.19 & 75.18 & 11668.17 \\
$1970-71$ & 1.82 & 1211.25 & 165.75 & 18541.82 \\
$1971-72$ & 2.56 & 1710.49 & 109.27 & 13079.12 \\
Surcharge for 1971-72 & -5.56 & 1710.49 & 148.75 & 13079.12 \\
Total 1971-72 & 2.56 & 179 & \\
\hline
\end{tabular}

\begin{tabular}{|c|c|c|c|}
\hline Slab No. 3 & $\begin{array}{l}\text { Price } \\
\text { between } \\
30 \text { paisa to } \\
\text { Re. } 1 \text { per } \\
10 \text { Cig. }\end{array}$ & Slab No. 4 & $\begin{array}{l}\text { Price } \\
\text { More than } \\
\text { Re. 1 per } \\
10 \text { Cig. }\end{array}$ \\
\hline
\end{tabular}

\begin{tabular}{cccccc}
\hline Rs. & Cig. & Rs. & Cig. & Rs. & Cig. \\
\hline 67.23 & 2446.46 & - & - & 135.78 & 18839.62 \\
70.89 & 2548.64 & - & - & 141.65 & 20096.06 \\
81.30 & 2982.41 & - & - & 160.27 & 20595.70 \\
87.83 & 3525.27 & - & - & 173.68 & 22278.63 \\
98.72 & 3192.39 & 28.01 & 312.31 & 294.30 & 23257.77 \\
69.31 & 2394.92 & 18.69 & 206.39 & 199.83 & 17390.92 \\
17.53 & - & 3.09 & - & 60.10 & - \\
86.84 & 2394.92 & 21.78 & 206.39 & 259.93 & 17390.92 \\
\hline
\end{tabular}

Figures are rounded upto two decimal points. 
Irfan: Incidence af Indirect Taxes

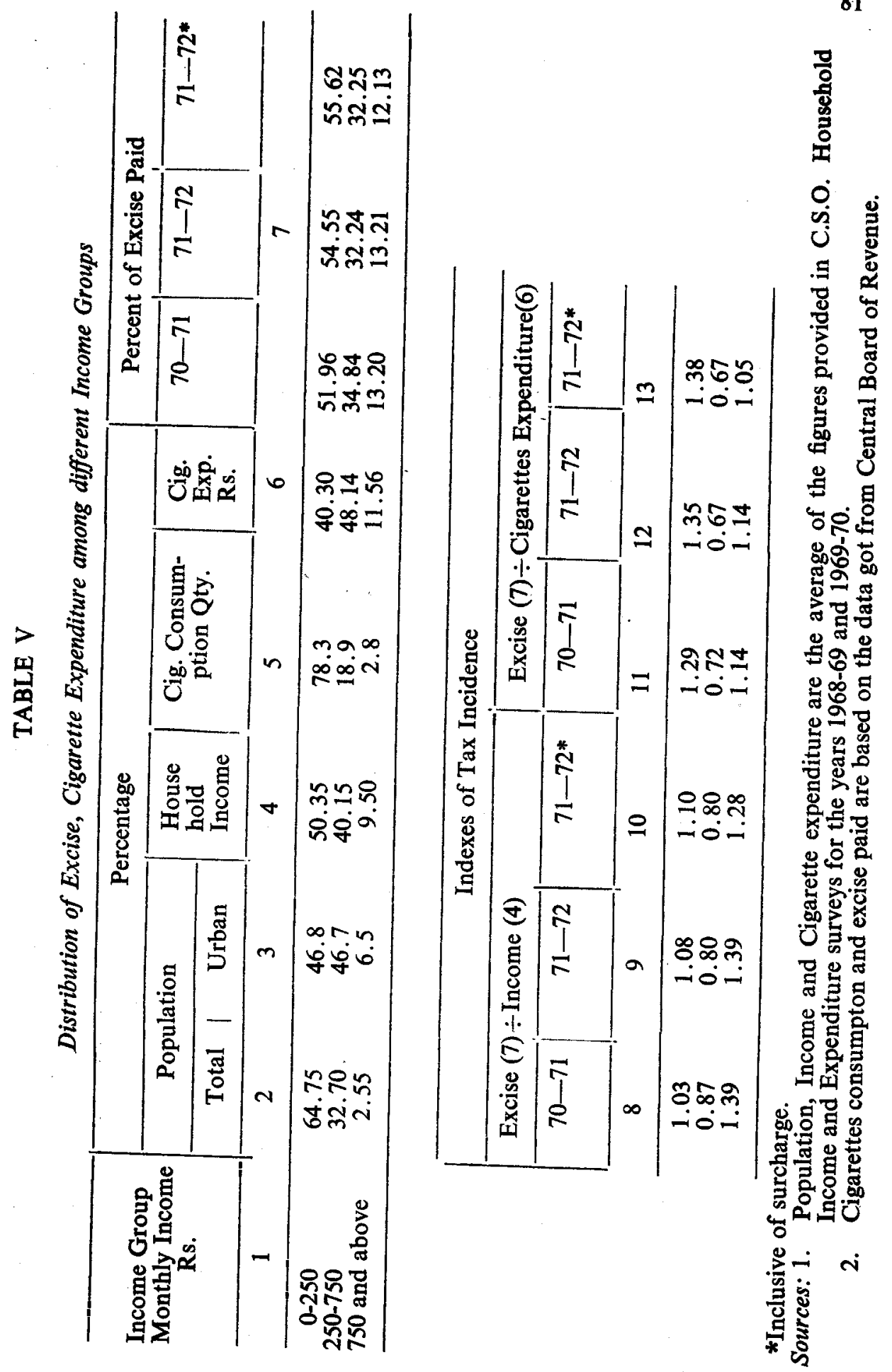




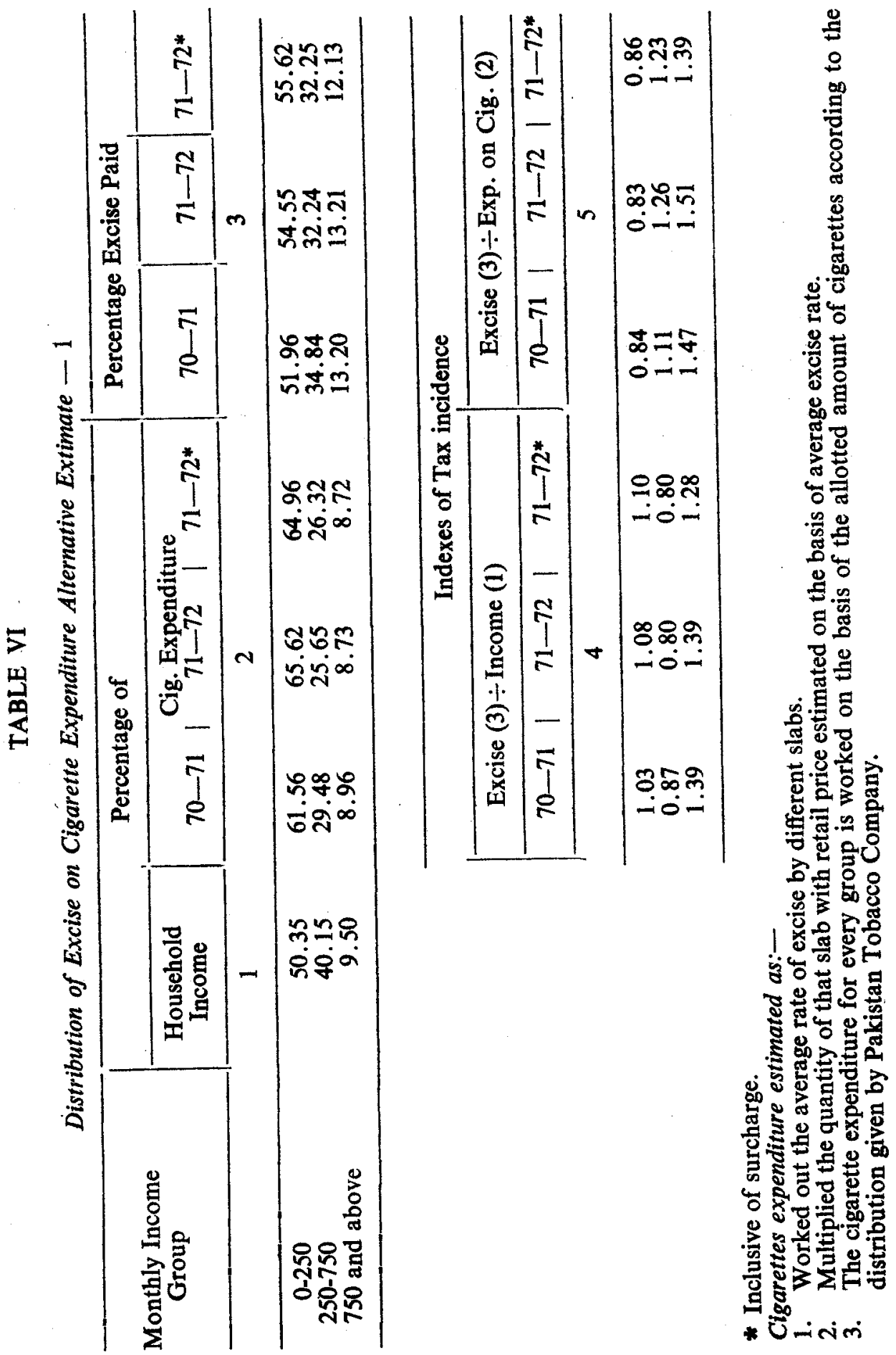




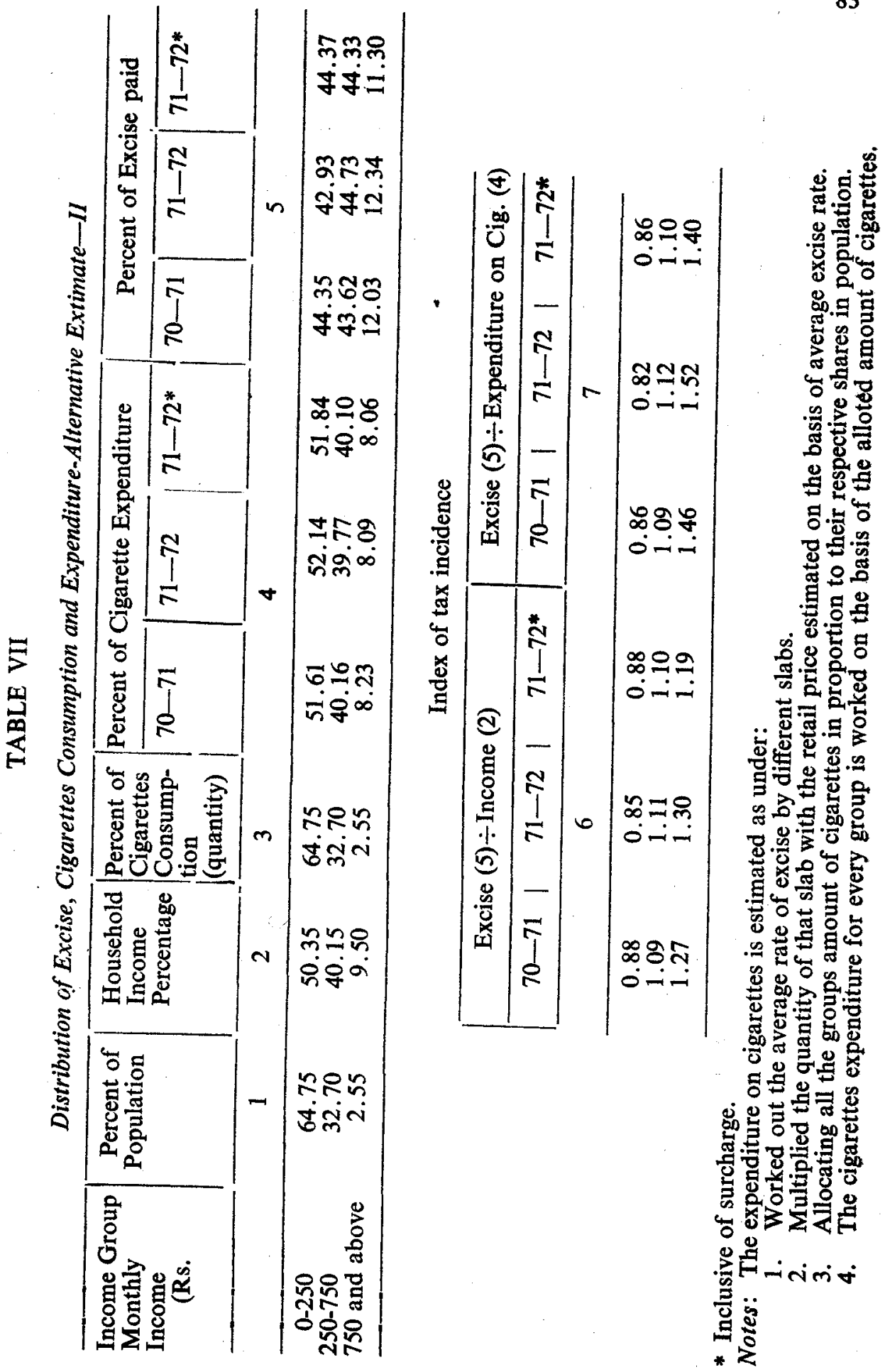




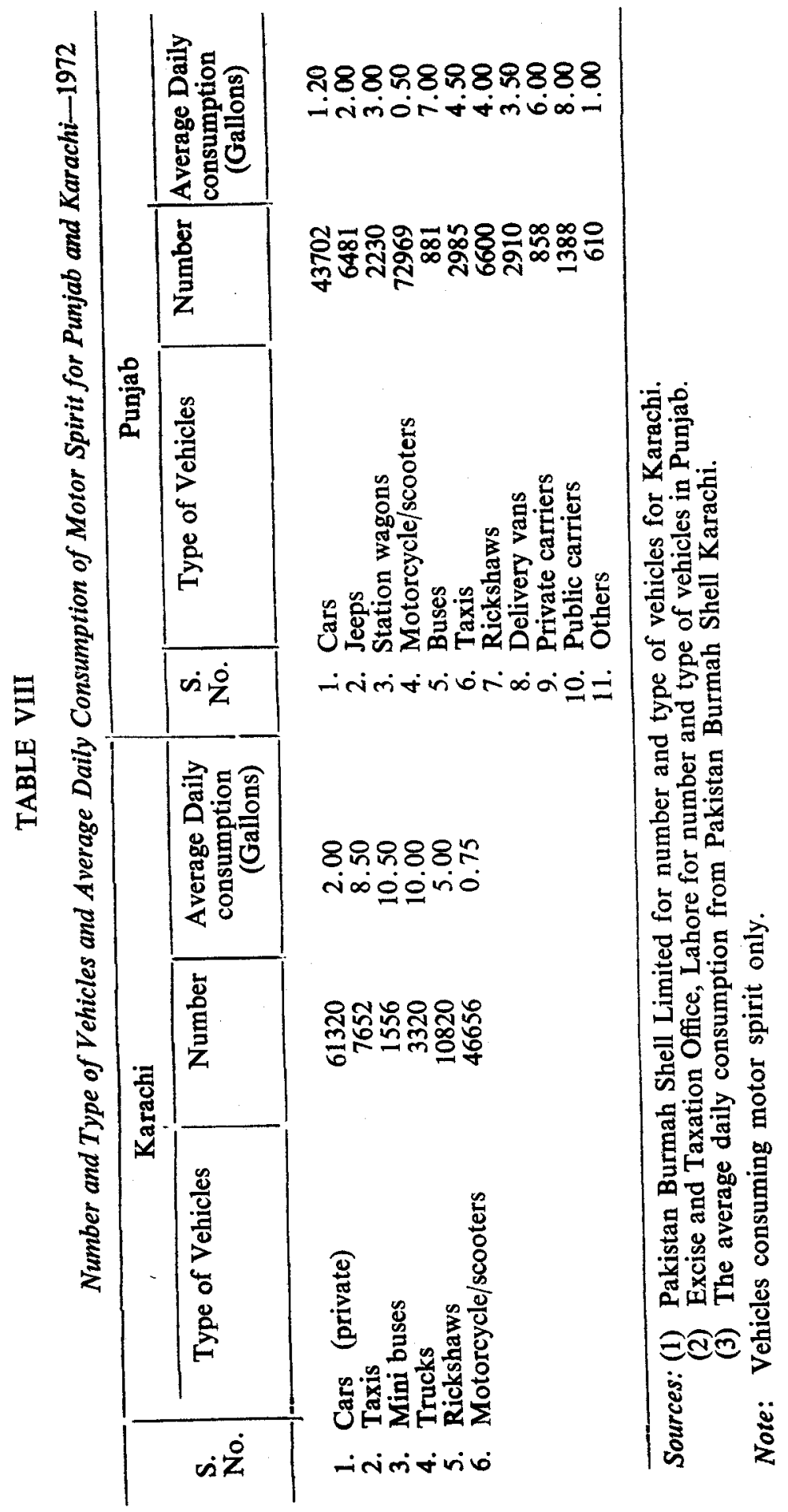




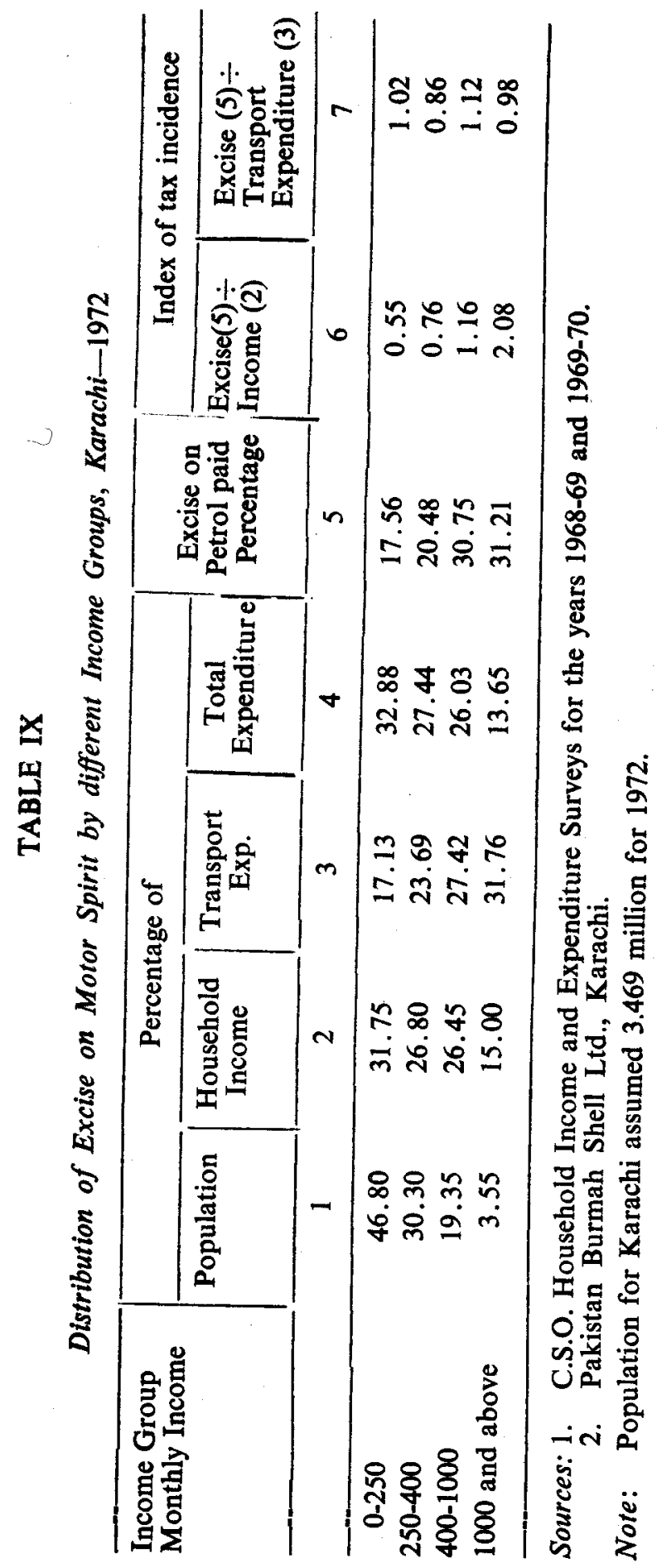




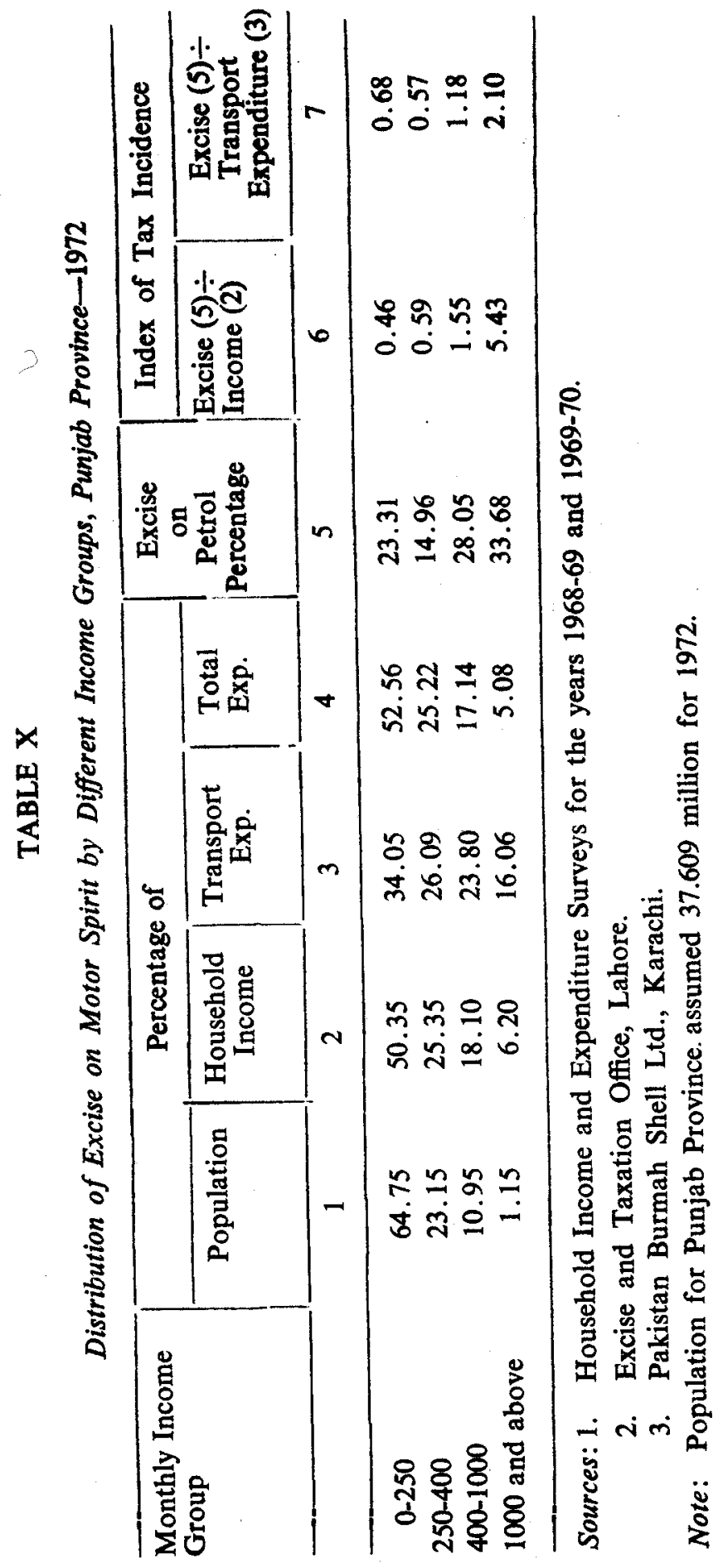




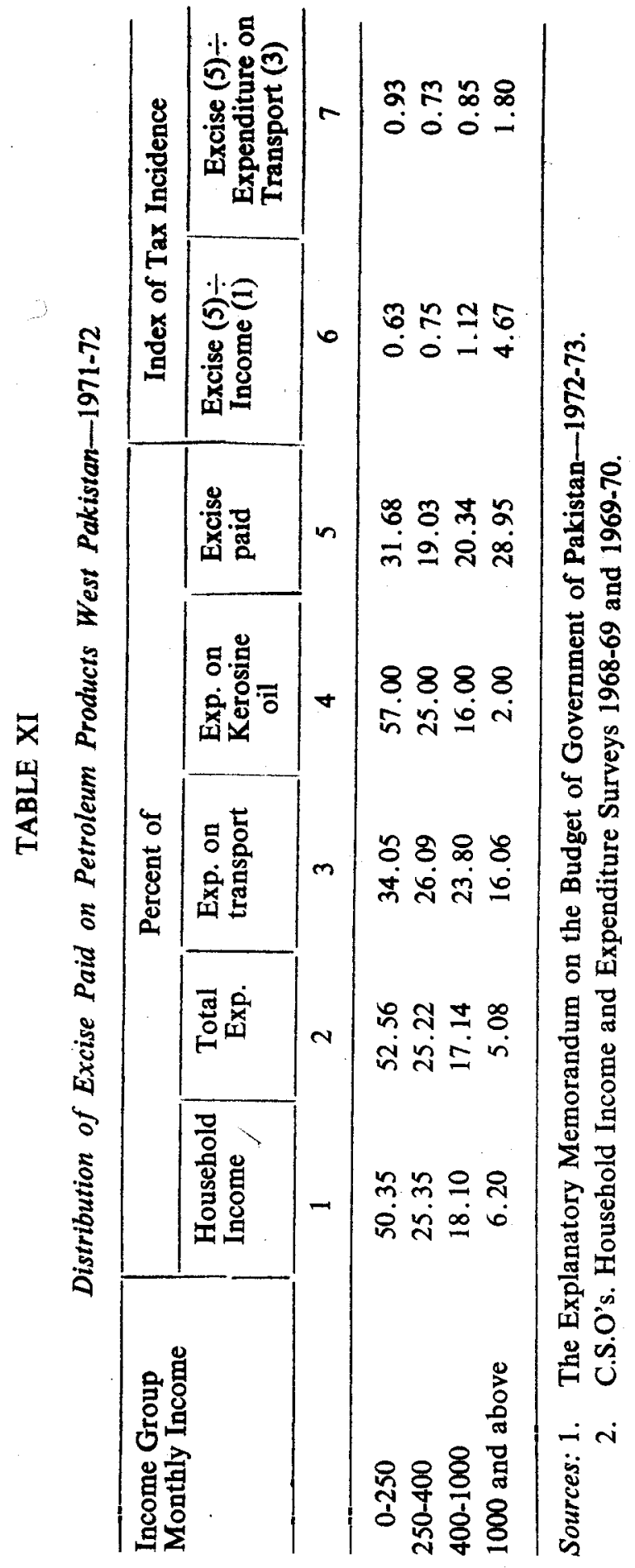

